\title{
Recovery of $\mathrm{SO}_{2}$ and $\mathrm{MgO}$ from By-Products of $\mathrm{MgO}$ Wet Flue Gas Desulfurization
}

\author{
Liyun Yan, ${ }^{\star}$ Xiaofeng Lu, ${ }^{\star \star}$ Quanhai Wang, and Qiang Guo \\ Key Laboratory of Low-Grade Energy Utilization Technologies and Systems, Ministry of Education, Chongqing University, \\ Chongqing, People's Republic of China.
}

Received: January 5, $2014 \quad$ Accepted in revised form: June 11, 2014

\begin{abstract}
An industrial demonstration unit using natural gas as a heat source was built to calcine the by-products of $\mathrm{MgO}$ wet flue gas desulfurization from power plants; influencing factors on the $\mathrm{SO}_{2}$ content in calciner gas were comprehensively analyzed; and an advantageous recycling condition of $\mathrm{MgO}$ and $\mathrm{SO}_{2}$ from by-products was summarized. Results showed that the $\mathrm{SO}_{2}$ content in the calciner gas was increased by more than 10 times under a lower excess air coefficient, a higher feed rate, a lower crystal water in by-products, and a higher feed port position. For the tests conducted under the excess air coefficient above and below one, the effect of the furnace temperature on the $\mathrm{SO}_{2}$ content in the calciner gas was reversed. Results of activity analysis indicate that particles of $\mathrm{MgO}$ generated under the calcination temperature of $900-1,000^{\circ} \mathrm{C}$ had a high activity. In contrast, due to the slight sintering, $\mathrm{MgO}$ generated under the calcination temperature of $1,100^{\circ} \mathrm{C}$ had a low activity. To recycle $\mathrm{SO}_{2}$ as well as $\mathrm{MgO}$, a temperature range of $900-927^{\circ} \mathrm{C}$ for TE103 is proposed. These studies will prompt the desulfurization market diversification, reduce the sulfur's dependence on imports for making sulfuric acid, be meaningful to balance the usage of the natural resource in China, and be regarded as a reference for the development of this technology for other similar developing countries.
\end{abstract}

Key words: activity; by-products; $\mathrm{MgO} ; \mathrm{SO}_{2}$

\section{Introduction}

A s CHINA's ENERGY STRUCTURe, it is unlikely to change the dominance of coal in the near future. According to the statistical data from the International Energy Agency (IEA), China will consume more than $50 \%$ of the global coal demand by 2014 (International Energy Agency, 2012). In China, the extensive use of coal has resulted in severe $\mathrm{SO}_{2}$ pollution problem, which has a harmful influence on both the environment and human health. In response, China has enacted the most stringent standards on $\mathrm{SO}_{2}$ emission (lower than $100 \mathrm{mg} / \mathrm{m}^{3}$ ) (Ministry of Environmental Protection and AQSIQ, 2011). To meet this standard, a high calcium-sulfur mole ratio was required in power plants to increase the absorption efficiency of $\mathrm{SO}_{2}$ in a limestone wet flue gas desulfurization (WFGD) system. Limestone WFGD technology

*Corresponding author: Key Laboratory of Low-Grade Energy Utilization Technologies and Systems, Ministry of Education, Chongqing University, Shapingba, Chongqing 400044, People's Republic of China. Phone: + 8623 65102475; Fax: + 8623 65102475; E-mail: yanziyly@sina.cn

**Corresponding author: Key Laboratory of Low-Grade Energy Utilization Technologies and Systems, Ministry of Education, Chongqing University, Shapingba, Chongqing 400044, People's Republic of China. Phone: +8623 65102475; Fax: +8623 65102475; E-mail:xf_luke@163.com is a dominant desulfurization technology in coal-fired power plants. As a result, it leads to some problems as follows. First, this aggravates the scale and plugging of limestone WFGD system. Second, it produces a huge amount of desulfurization gypsum, which not only occupies the land resources but also leads to the re-pollution. Third, the over-mining of limestone leads to the destruction of forest vegetation, which is harmful to the ecological environment and damages the coordinated development of the energy structure.

To solve these problems, the $\mathrm{MgO}$ flue gas desulfurization (FGD) process can been used to replace the limestonegypsum desulfurization process for the following reasons. First, the process system of the FGD using $\mathrm{MgO}$ is similar to using limestone, but simpler in comparison to it (Chai et al., 2006). It is easy to replace the process of the FGD with limestone. Second, lower sorbent consumption and fewer by-products are generated using MgO FGD compared with limestone (Rosemount Analytical, Inc., 2013). Third, Mg $(\mathrm{OH})_{2}$ gives a higher scrubbing capacity (Sajan et al., 2007) and the by-products $\left(\mathrm{MgSO}_{3} \cdot 6 \mathrm{H}_{2} \mathrm{O}\right.$ and $\left.\mathrm{MgSO}_{4} \cdot 7 \mathrm{H}_{2} \mathrm{O}\right)$ can be recycled. Fourth, the problems of the scale and plugging in MgO FGD system can be eased (Sargent and Lundy, 2003).

In recent years, the research on the $\mathrm{MgO}$ desulfurization process mainly has focused on the following aspects. Sajan et al. (2007) studied the gas absorption in slurries of fine particles: $\mathrm{SO}_{2}-\mathrm{Mg}(\mathrm{OH})_{2}-\mathrm{MgSO}_{3}$ system. Recelj and Golob 
(2001) studied the absorption of $\mathrm{SO}_{2}$ in the $\mathrm{MgO}-\mathrm{SO}_{2}-\mathrm{H}_{2} \mathrm{O}$. Zhang et al. (2011) studied the effects of crystallization conditions on the performances of the by-product recovering process. Wang et al. (2013) studied the macrokinetics of magnesium sulfite oxidation inhibited by ascorbic acid. $\mathrm{Xu}$ et al. (2010) simulated and optimized the processes of Magnesia FGD. Shen et al. (2012) studied the kinetics and mechanism of sulfite oxidation in the magnesium-based wet FGD process. Kang (2011) studied the effect of pyrolysis temperature on the activity of $\mathrm{MgO}$ generated from the decomposition of the by-products using a pipe furnace. Shen et al. (2013) studied the magnesium-based wet FGD process with oxidation inhibition of the by-product. Chen et al. (2009) studied the thermo-gravimetric kinetics of $\mathrm{MgSO}_{3} \cdot 6 \mathrm{H}_{2} \mathrm{O}$ byproduct from Magnesia wet FGD. Guo et al. (2011) studied the dissolution rate of magnesium hydrate for WFGD. Bitsko and Helt (1991) studied the problems with magnesium oxide regenerable scrubbers. Besides, Koyama (1998), Yi et al. (2009), Wang et al. (2010), and Xiong (2005, 2013) have applied a series of patents in this area.

Little research has been found on the industrial application of the regenerable $\mathrm{MgO}$ FGD process, although this process is a feasible means of $\mathrm{SO}_{2}$ emission control, which has been evaluated objectively based on operational experience in the United States (United States Environmental Protection Agency, 1981). In this process, $\mathrm{SO}_{2}$ is removed in a wet scrubber and the $\mathrm{MgSO}_{3} / \mathrm{MgSO}_{4}$ product results from $\mathrm{SO}_{2}$ absorption in a scrubber. The absorbed product is dried and calcined in a calciner to regenerate $\mathrm{MgO}$ for FGD, and $\mathrm{SO}_{2}$ captured during calcinations is suitable for sulfuric acid production (McGlamery et al., 1973). This process is very important for China, because there are abundant resources of magnesium and poor resources of sulfur in China. In this process, the controlling $\mathrm{SO}_{2}$ mole fraction in calciner gas and the activity of $\mathrm{MgO}$ generated during calcinations are a key technology. However, the industrial experiment and study on the influencing factors on the $\mathrm{SO}_{2}$ mole fraction and the activity of the $\mathrm{MgO}$ generated during calcining have been scarcely involved.

Against this backdrop, a 0.3MWe industrial demonstration unit was built. The effects of excess air coefficient, feed rate of by-products, furnace temperature, crystal water content in by-products, and feed port position on the $\mathrm{SO}_{2}$ mole fraction in the calciner gas were studied. The effect of the furnace temperature on the activity of the generated $\mathrm{MgO}$ was also studied in this article.

\section{Experimental}

\section{Materials}

By-products of magnesia FGD were from a desulfurization system in a $300 \mathrm{MWe}$ coal-fired power plant. The composition analysis of by-products is shown in Table 1 .

\section{Methods}

By-products were calcined using an industrial demonstration unit, as shown in Fig. 1a. The arrangement of testing points is shown in Fig. 1b. The image of the experimental unit is shown in Fig. 2.

The main body of the unit was a fluidized bed calciner, which included a cylindrical furnace (internal diameter of
Table 1. Component Analysis of By-Products

\begin{tabular}{llccrcc}
\hline & \multicolumn{5}{c}{ Component (\%) } \\
\cline { 2 - 6 } Case & $\mathrm{MgSO}_{3}$ & $\mathrm{MgSO}_{4}$ & $\begin{array}{c}\text { Crystal } \\
\text { water }\end{array}$ & $\mathrm{MgCO}_{3}$ & $\mathrm{MgO}$ & $\mathrm{S}(\%)$ \\
\hline 1 & 25.32 & 23.39 & 30.99 & 10.99 & 1.54 & 14.03 \\
2 & 28.7 & 21.39 & 25.65 & 9.59 & 4.43 & 14.53 \\
3 & 26.54 & 20.34 & 26.08 & 13.58 & 4.33 & 13.59 \\
\hline
\end{tabular}

$500 \mathrm{~mm}$ and height of 7,000 $\mathrm{mm}$ ), an air chamber, and an air distribution plate. The auxiliary systems included a feeding system, a flue gas system, a water system, and a data measurement and acquisition system. The workflow process is as follows.

Flue gas system. The high-pressure airflow from the air preheater entered the furnace from the air chamber to fluidize the bed materials. The introduced natural gas from the three nozzles evenly distributed in the same circumference of the furnace ( $66 \mathrm{~mm}$ away from the air distribution plate) was burned above the material layer. The bed material was heated until the furnace temperature reached approximately $1,000^{\circ} \mathrm{C}$. After the flue gas was exhausted from the furnace, it passed through the air preheater, which acted as a heat exchanger, and then entered the cyclone segregator. After the gas-solid separation in the cyclone segregator, the remaining solid particles were cooled down by a nash cooler and collected in a dust collector. The gas was introduced into an alkali absorption tower via two draft fans, and was then discharged.

Material system. The magnesium oxide desulfurization by-products were stored in a feed bin after pulverization. A metering screw conveyor was used to send the by-products to a Venturi feeder (driven by high-pressure air), which was used to feed the materials into the fluidized bed calciner through a material nozzle.

Six sampling points (SP1, SP2, SP3, SP4, SP5, and SP6) along the calciner height direction were set to analyze the distribution of $\mathrm{SO}_{2}$ in the calciner, and the sampling point $\mathrm{SP} 1$ was also set to analyze the $\mathrm{SO}_{2}$ mole fraction in calciner gas exiting the furnace. The mole fractions of $\mathrm{O}_{2}$ and $\mathrm{CO}_{2}$ along the calciner height direction (SP1, SP2, SP3, SP4, SP5, and SP6) were measured online using Testo-MGA5 flue gas analyzer. The low mole fraction $\mathrm{SO}_{2}(0-0.5 \%)$ was also measured using this method. The high mole fraction $\mathrm{SO}_{2}$ was measured by iodometry. A set of gas and particle sampling device was made referencing GB-T-16157-1996 (State environmental protection administration, 1996), as shown in Fig. 3. The sampling conditions for the activity analysis of the $\mathrm{MgO}$ generated by calcinations of by-products are the case 2 in Table 1 , feed rate of $89.6 \mathrm{~kg} / \mathrm{h}$, furnace temperature (TE103) of $900^{\circ} \mathrm{C}, 1,000^{\circ} \mathrm{C}$, and $1,100^{\circ} \mathrm{C}$, respectively. The sampling point is in SP1. The analysis of the activity includes the following contents. The particle-sized distributions of samples obtained from the calciner outlet, the gassolid separator outlet, and the bottom of the furnace were determined. The morphology of the generated $\mathrm{MgO}$ by calcining by-products was characterized with SEM. The magnification of SEM images is 8,000, and the view field is 
a

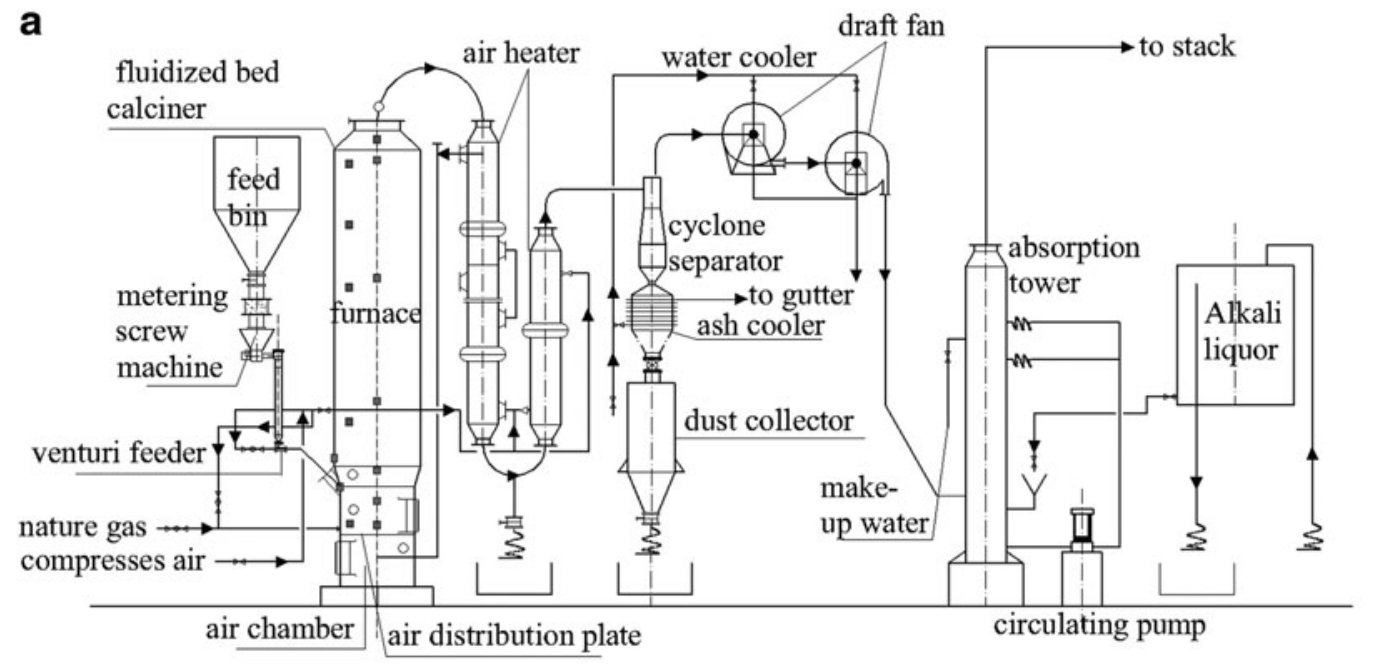

b

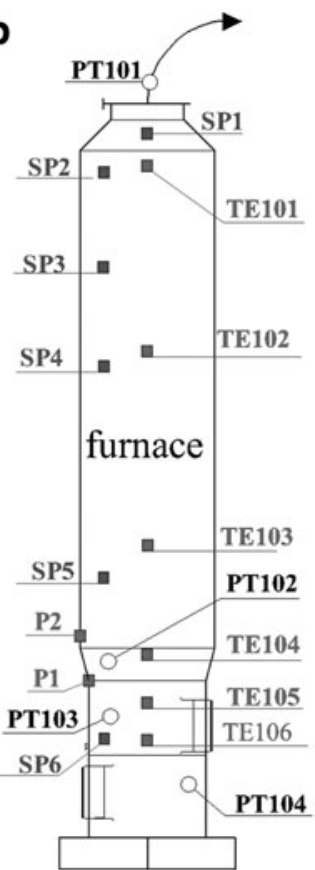

FIG. 1. Industrial demonstration unit and arrangement of measuring points (a) Industrial demonstration unit (b) arrangement of measuring points SP: Sampling point, TE: Temperature measuring point, PT: Pressure measuring point, P1: Original position of feed port, P2: Position after heightening feed port.

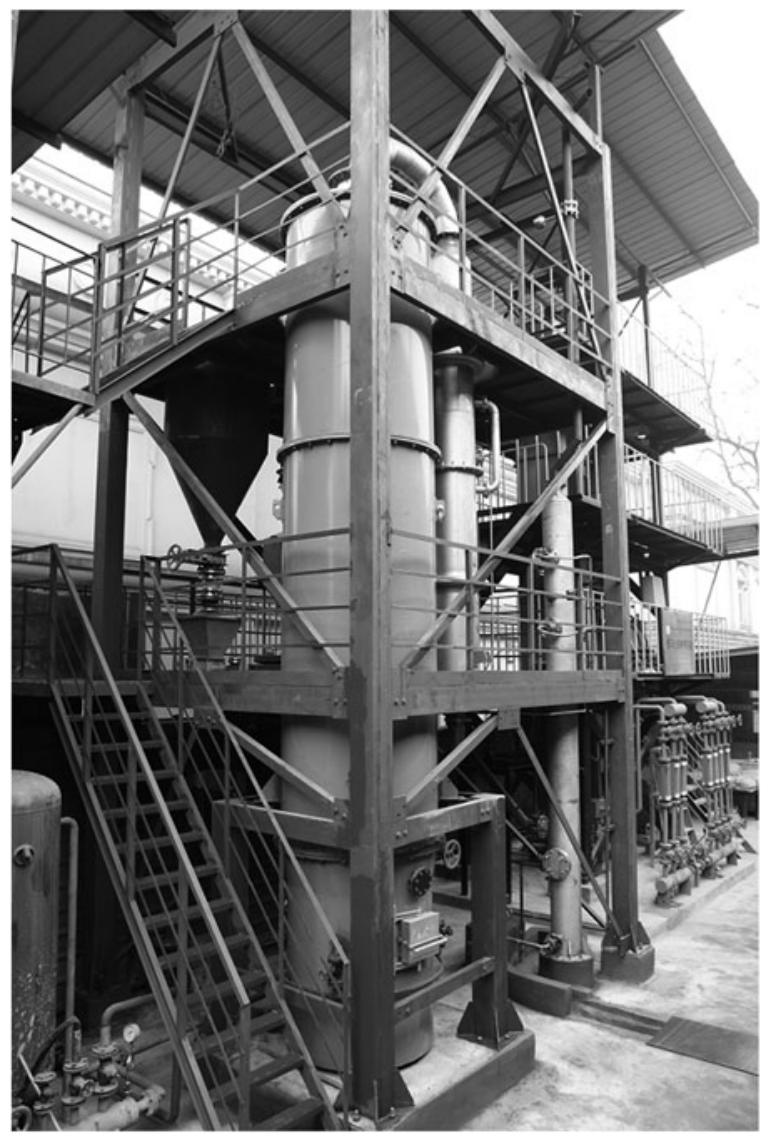

FIG. 2. Industrial demonstration unit.
$18.06 \mu \mathrm{m}$. Using a color indicator, the reaction of $\mathrm{MgO}$ and citric acid was monitored and the activity of $\mathrm{MgO}$ was determined.

\section{Results and Discussion}

\section{Features of furnace temperature}

The curve of the average temperature increase of the furnace as a function of time is shown in Fig. 4, and the temperature distributions along the furnace under the conditions of different operating conditions are shown in Fig. 5. As shown in Fig. 4, the fluidized bed calciner could be heated to the thermal decomposition temperature of the by-products (Zhang et al., 2010; Scheidema and Taskinen, 2011), and the temperature could be maintained at a constant value over a long processing time. As shown in Fig. 5, the temperature from TE106 to TE105 rapidly decreased due to material absorbing heat for the feed port (located in the position P1) closer to TE105. The temperature from TE105 to TE103 increased due to the complete combustion of nature gas, and then again decreased for the endothermic reaction of byproducts and the heat storage of the furnace wall.

\section{$\mathrm{O}_{2}, \mathrm{SO}_{2}$, and $\mathrm{CO}_{2}$ mole fractions along the calciner height direction}

In this experiment, the mole fractions of $\mathrm{O}_{2}, \mathrm{SO}_{2}$, and $\mathrm{CO}_{2}$ along the calciner height direction for case 1 in Table 1 are shown in Fig. 6. It can be found from Fig. 6 that there existed a transition point with a relative distance of 0.55 . Downstream of this transition point, the $\mathrm{SO}_{2}$ and $\mathrm{CO}_{2}$ content rapidly increased; while e upstream of this point, variances of the $\mathrm{SO}_{2}$ and $\mathrm{CO}_{2}$ content varied slowly. The changing tendency of $\mathrm{O}_{2}$ mole fractions is contrary. This phenomenon 
FIG. 3. Sampling system.

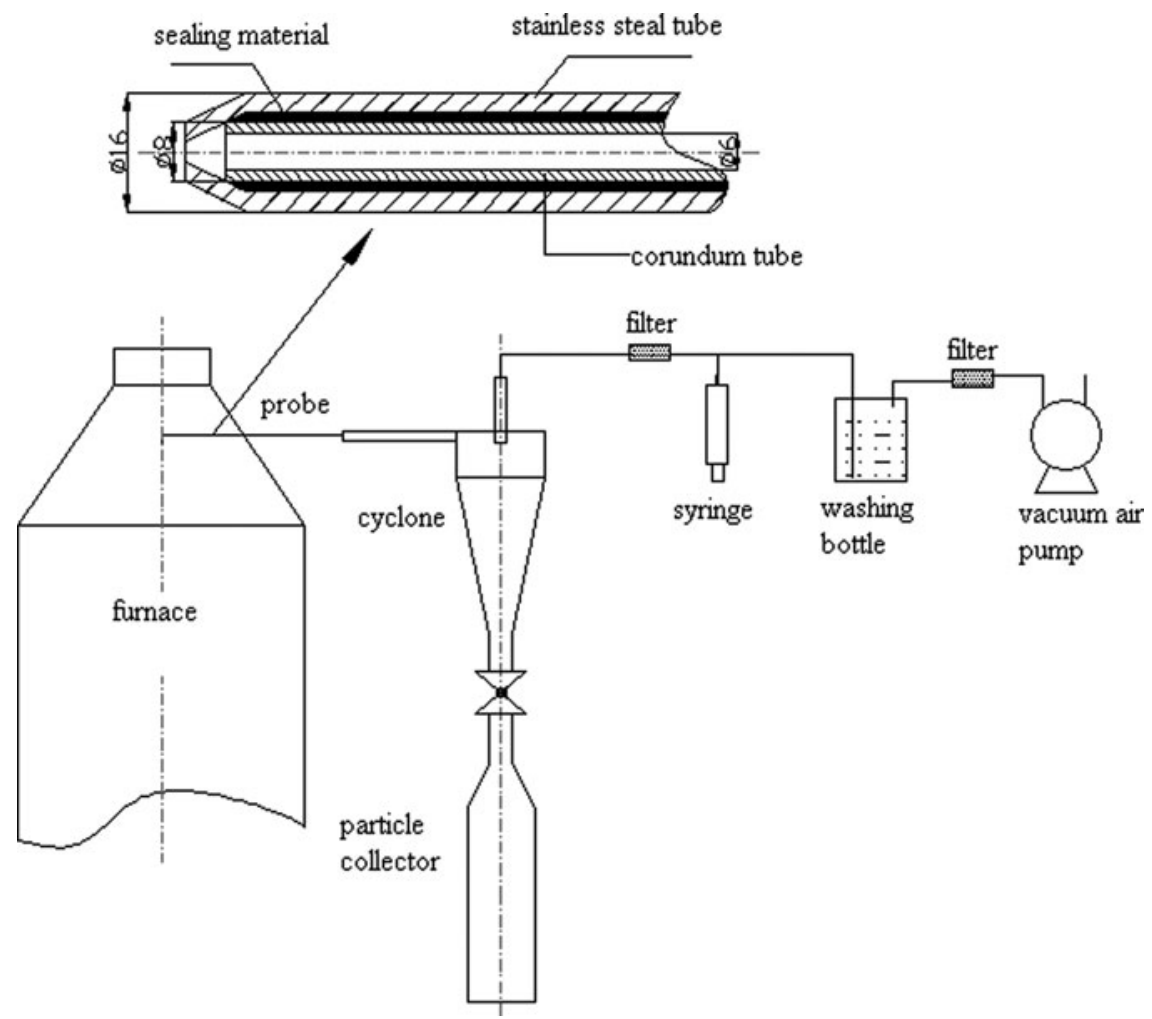

shows that the decomposition reaction of by-products and fuel combustion mainly occurred in the lower zone of the furnace.

It is found that the maximum value of the feed rate was $60 \mathrm{~kg} / \mathrm{h}$ and the ratio of air to nature gas was larger under the conditions of the feed port located in the position P1 $(525 \mathrm{~mm}$ away from the air distribution) and crystal water content of $30.99 \%$ in the by-products. If the feed rate was more than $60 \mathrm{~kg} / \mathrm{h}$, it was easy to spray material on the opposite furnace wall and air distribution plate. As a result, the amount of slag in the bottom of the furnace increased and the thermal decomposition rate of by-products decreased. To solve this problem, the feed port was raised to the position P2 $(810 \mathrm{~mm}$ away from the air distribution) in the furnace and the by-

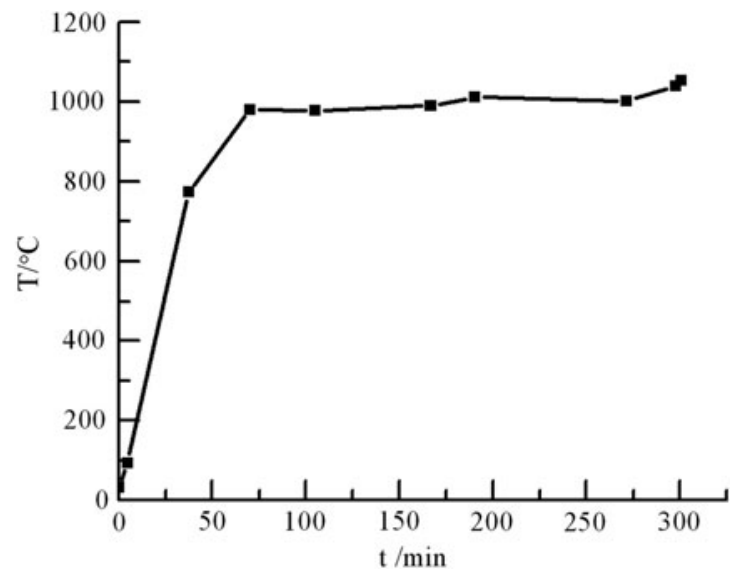

FIG. 4. Heating curve. products were dried. After that, the feed rate can be improved to $90 \mathrm{~kg} / \mathrm{h}$, the ratio of the air to nature gas can be decreased, and the rate of thermal decomposition of by-products can be increased.

The relationship between the $\mathrm{SO}_{2}$ mole fractions and time, and the effects of the position of feed port, excess air coefficient, feed rate, furnace temperature, and the crystal water content in by-products on the $\mathrm{SO}_{2}$ mole fractions in calciner gas are discussed as follows.

\section{Relationships between the $\mathrm{SO}_{2}$ mole fractions and time}

The relationship between the $\mathrm{SO}_{2}$ mole fractions in calciner gas and time is shown in Fig. 7 under the conditions of the different feed rate, the position of feed port, and excess air coefficient. The expression for the excess air coefficient $\alpha$ is shown in formula (1).

$$
\alpha=\frac{V}{V_{0}}
$$

where $V$ and $V_{O}$ represent the actual and theoretical air volume for fuel complete combustion, respectively.

It is found that the $\mathrm{SO}_{2}$ mole fractions increased quickly in the first $6 \mathrm{~min}$ under the conditions of the feed port located at the position $\mathrm{P} 1$, feed rate of $60 \mathrm{~kg} / \mathrm{h}$, and excess air coefficient of 1.19 , then changed slowly, and finally stabilized to $0.38 \%$. Under the conditions of the feed port located at the position $\mathrm{P} 2$, feed rate of $89.6 \mathrm{~kg} / \mathrm{h}$, and excess air coefficient of 0.92 , the $\mathrm{SO}_{2}$ mole fractions increased quickly in the first $8 \mathrm{~min}$. Finally, the $\mathrm{SO}_{2}$ mole fractions stabilized at $4.67 \%$. Ideally, the $\mathrm{SO}_{2}$ content in the calciner gas should be $4.8 \%$ depending on the $\mathrm{S}$ content in the by-products and the measured flow rate of the flue gas. Therefore, elevating the position of 


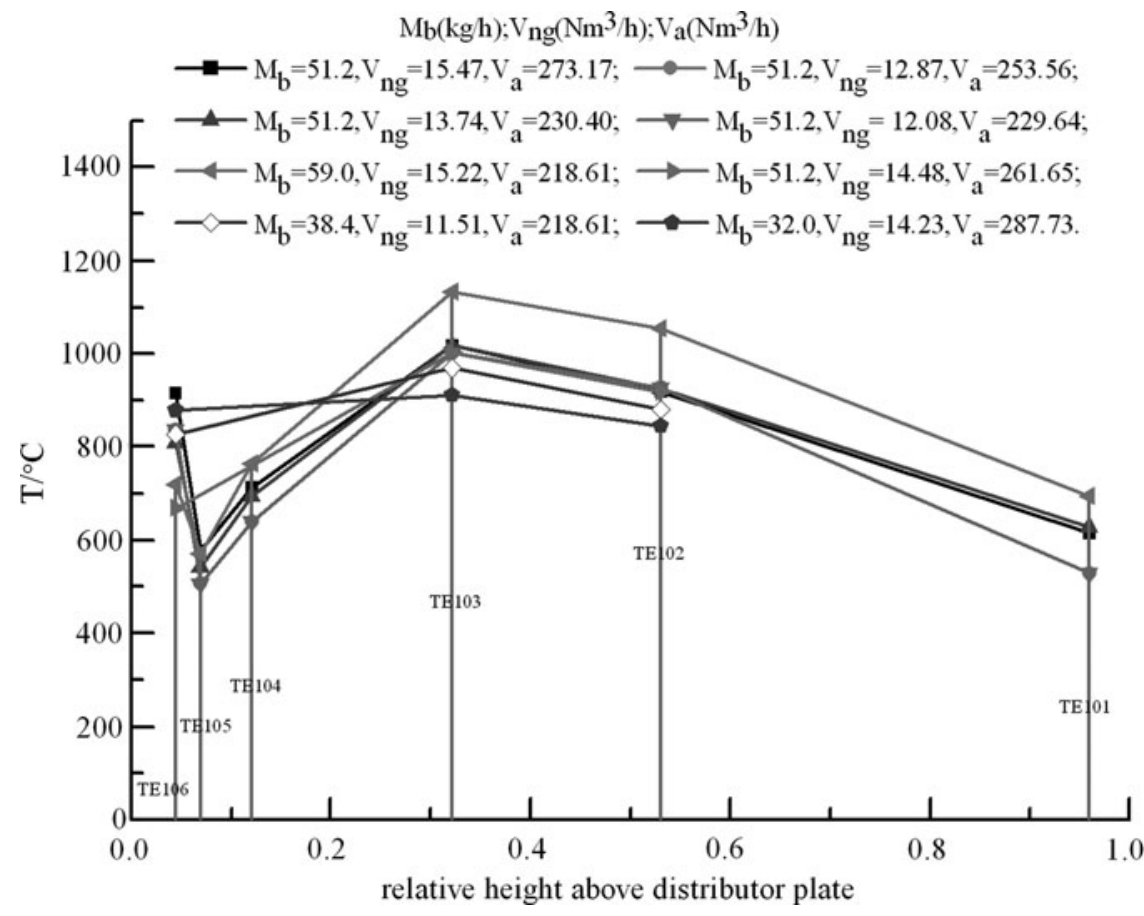

FIG. 5. Temperature distributions along furnace.

the feed port to the position $\mathrm{P} 2$, increasing feed rate, and decreasing excess air coefficient are beneficial to improve the $\mathrm{SO}_{2}$ mole fractions in calciner gas. This article separately analyzed the effects of these factors on the $\mathrm{SO}_{2}$ mole fractions in the next section.

\section{Effect of excess air coefficient on the $\mathrm{SO}_{2}$ mole fractions in the calciner gas}

The effect of the excess air coefficient on the $\mathrm{SO}_{2}$ mole fractions is shown in Fig. 8. Figure 8 demonstrates that the $\mathrm{SO}_{2}$ mole fractions decreased with the increment of the excess air coefficient, because the increasing excess air coefficient would change the reaction path of by-products and flue gas volume in calciner gas.

Global reaction mechanisms for the calcining processes in the furnace are shown as follows (McGlamery et al., 1973;

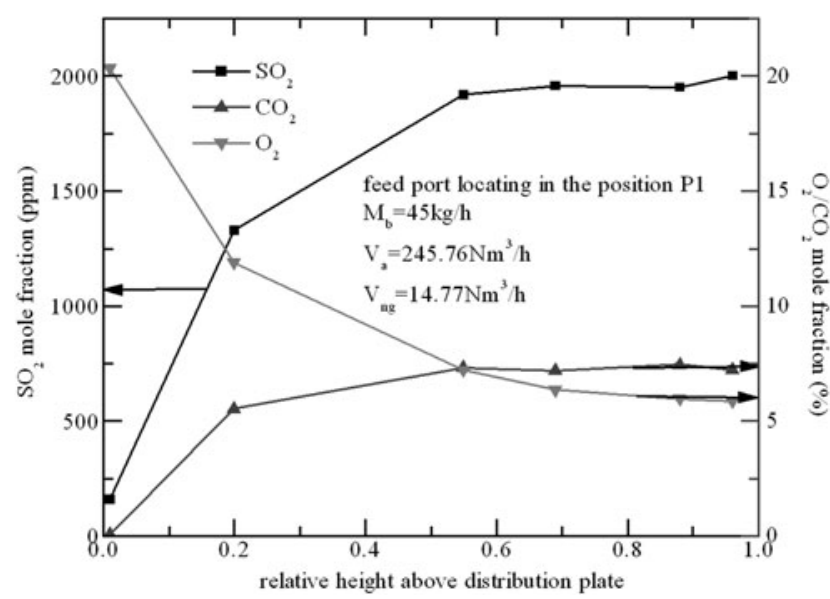

FIG. 6. Distributions of $\mathrm{O}_{2}, \mathrm{CO}_{2}$, and $\mathrm{SO}_{2}$ along furnace.
Gangwal and Porter, 1995; Little, 1997; Pradyot, 2003; Guo, 2011).

$$
\begin{aligned}
& \mathrm{CH}_{4}+2 \mathrm{O}_{2} \rightarrow 2 \mathrm{H}_{2} \mathrm{O}+\mathrm{CO}_{2} \quad(\mathrm{R} 1) \\
& \mathrm{MgSO}_{3} \rightarrow \mathrm{MgO}+\mathrm{SO}_{2} \quad(\mathrm{R} 2) \\
& \mathrm{MgSO}_{4} \rightarrow \mathrm{MgO}+\mathrm{SO}_{2}+1 / 2 \mathrm{O}_{2} \quad \text { (R3) } \\
& \mathrm{CH}_{4}+3 / 2 \mathrm{O}_{2} \rightarrow 2 \mathrm{H}_{2} \mathrm{O}+\mathrm{CO} \quad(\mathrm{R} 4) \\
& \mathrm{MgSO}_{4}+\mathrm{CO} \rightarrow \mathrm{MgO}+\mathrm{CO}_{2}+\mathrm{SO}_{2} \quad \text { (R5) } \\
& \mathrm{CH}_{4}+2 \mathrm{SO}_{2} \rightarrow \mathrm{CO}_{2}+2 \mathrm{H}_{2} \mathrm{O}+2 \mathrm{~S} \quad \text { (R6) }
\end{aligned}
$$

It can be found that reactions (R3) and (R5) are two main paths for the destruction of $\mathrm{MgSO}_{4}$. The path of (R3) becomes active under a high temperature and an oxidization atmosphere. With regard to the (R5) path, it is activated under the reducing atmosphere. Meanwhile, its initial temperature is $300^{\circ} \mathrm{C}$ or so lower than that of reaction (R3) (Zhang et al.,

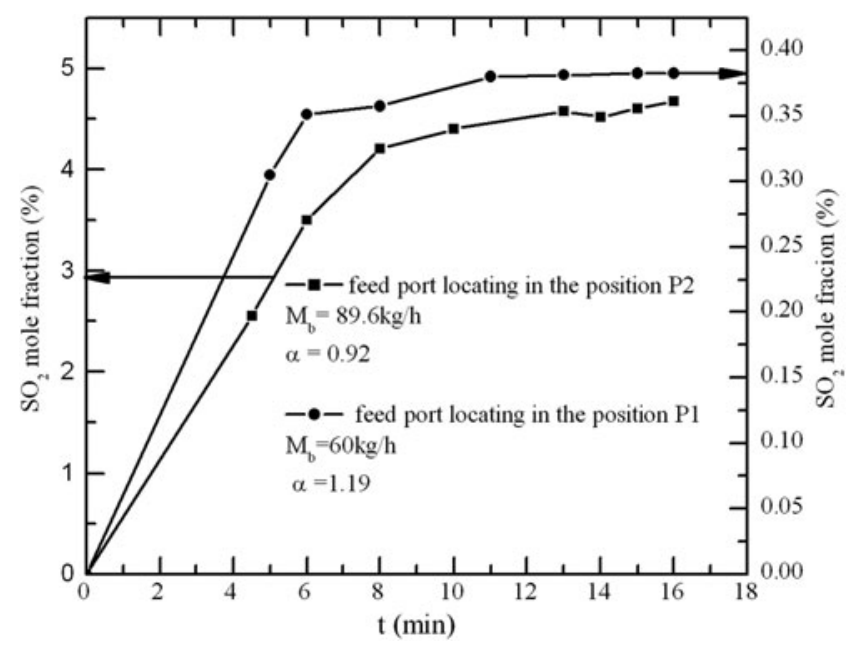

FIG. 7. Relationship between the $\mathrm{SO}_{2}$ mole fraction and time. Feed port located in the position P1 for case 1 in Table 1; feed port located in position P2 for case 2 in Table 1. 


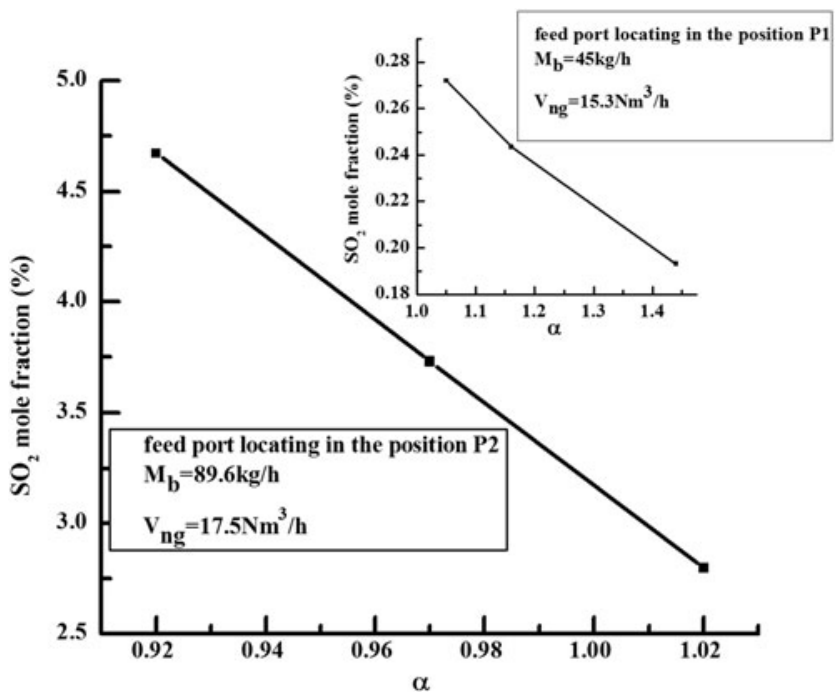

FIG. 8. Effect of air excess coefficient on $\mathrm{SO}_{2}$ mole fractions. Feed port located in position $\mathrm{P} 1$ for case 1 in Table 1; feed port located in position P2 for case 2 in Table 1 .

2010; Sun et al., 2013), implying that the materials need absorbing less heat to reach (R5)'s initial temperature in comparison with (R3). Therefore, it just needs less gas supply for the destruction of $\mathrm{MgSO}_{4}$ to be activated through the (R5) path. In addition, the amount of flue gas can be decreased, and the $\mathrm{SO}_{2}$ mole fractions can be simultaneously increased. However, the mole ratio of the earlier reactions show that if the mole ratio of nature gas to air is above 1/7.2, the generated $\mathrm{SO}_{2}$ is reduced to elemental sulfur according to (R6), which leads to a decrease of $\mathrm{SO}_{2}$ content in the calciner gas. As a result, the optimal operation can be built under the conditions of a reducing atmosphere and the mole ratio of nature gas to air lower than $1 / 7.2$.

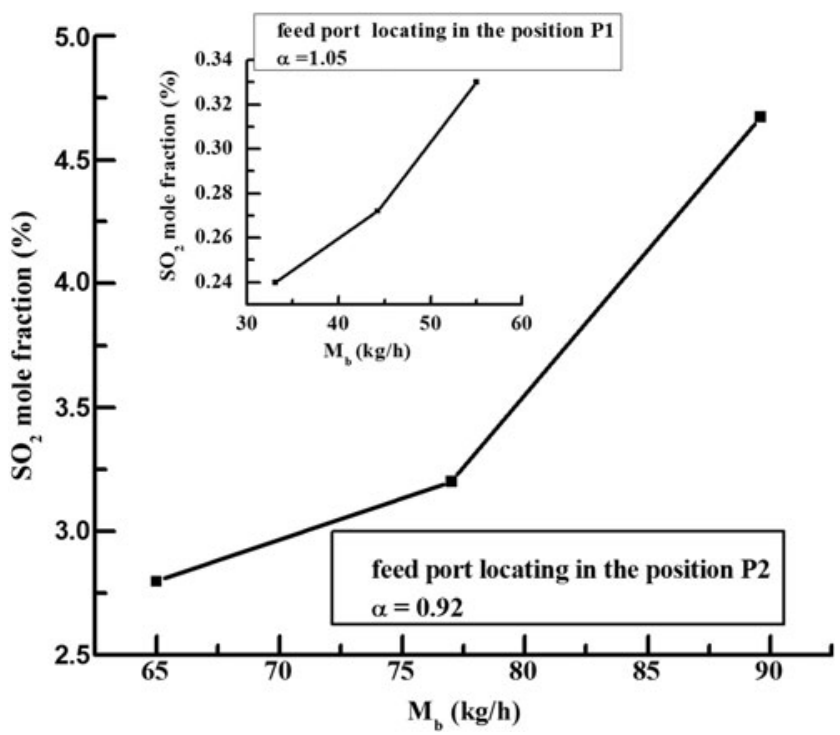

FIG. 9. Effect of feeding rate on $\mathrm{SO}_{2}$ mole fractions. Feed port located in position P1 for case 1 in Table 1; feed port located in position P2 for case 2 in Table 1.

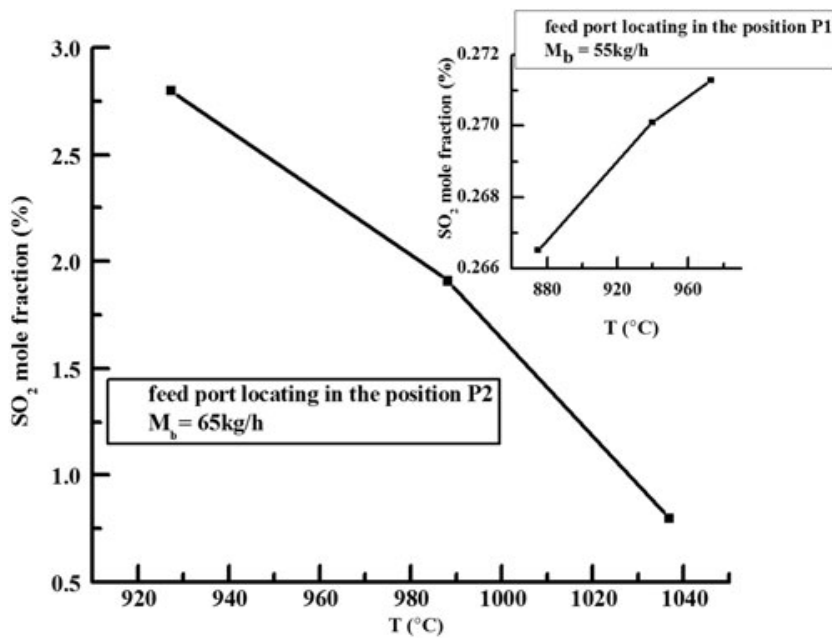

FIG. 10. Effect of furnace temperature on $\mathrm{SO}_{2}$ mole fractions.

Effect of feed rate of by-products on the $\mathrm{SO}_{2}$ mole fractions in calciner gas

The feed rate can change the particle concentration and temperature in the furnace, which can affect particle heating, thermal decomposition of the by-products, and $\mathrm{SO}_{2}$ mole fractions in the calciner gas. The high particle concentration is needed to get the high $\mathrm{SO}_{2}$ mole fractions, while the higher particle concentration may lead to the increasing amount of the unreacted by-products in the gas leaving the furnace.

Figure 9 shows that as the feed rate increased, the $\mathrm{SO}_{2}$ mole fractions also increased. $\mathrm{SO}_{2}$ mole fraction in calciner gas was $4.67 \%$ if the feed rate of the by-products was $89.6 \mathrm{~kg} / \mathrm{h}$. The $\mathrm{SO}_{2}$ mole fractions did not decrease as the feed rate of by-products increased in this figure. The reasons are as follows.

The particle concentration in furnace can be calculated by $\rho_{\mathrm{p}}=\Delta \mathrm{P} /(\Delta \mathrm{h} \cdot g)$ (Zhou et al., 2012), where $\rho_{\mathrm{p}}$ is particle concentration, $\mathrm{kg} / \mathrm{m}^{3} ; \Delta \mathrm{P}$ is pressure difference along the axial direction of the furnace, and its values are $96.19 \mathrm{~Pa}$, 122.30 Pa, and $179.00 \mathrm{~Pa}$, respectively. The corresponding

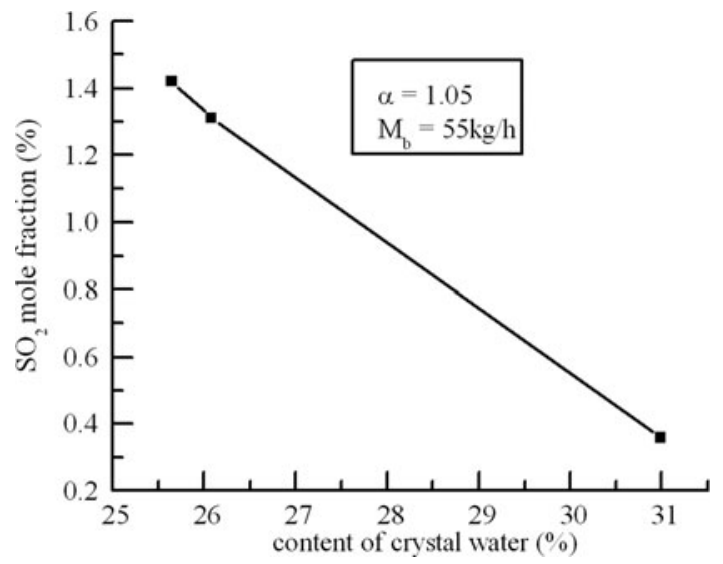

FIG. 11. Effect of crystal water content in by-products on $\mathrm{SO}_{2}$ mole fractions. 


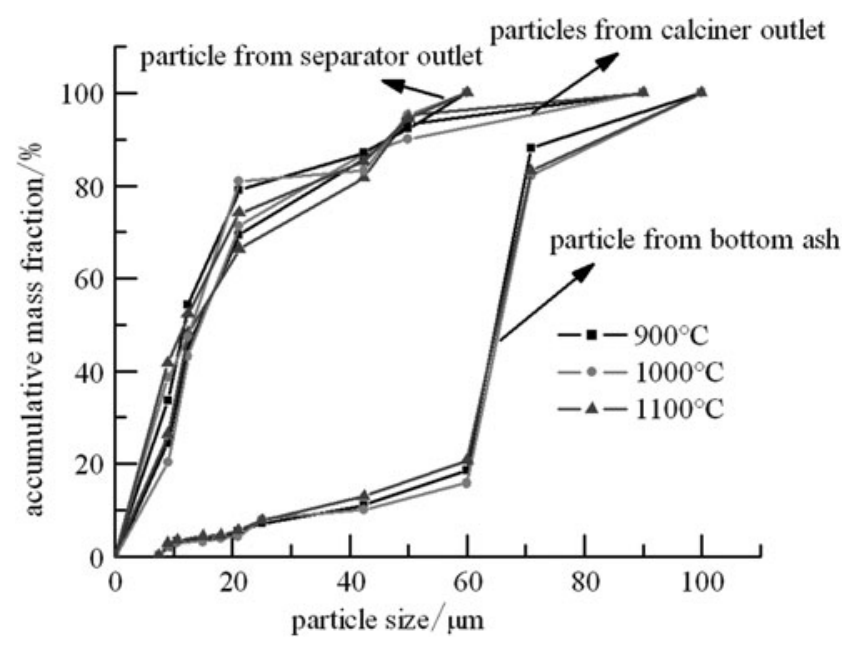

FIG. 12. Particle-sized distribution of $\mathrm{MgO}$ from calcinered by-products.

feed rates were $65.0,77.0$, and $89.6 \mathrm{~kg} / \mathrm{h}$, respectively; $g$ is acceleration of gravity, $9.8 \mathrm{~m} / \mathrm{s}^{2}$; and $\Delta \mathrm{h}$ is the height difference between two points, $6.50 \mathrm{~m}$. The pressure difference can be calculated by the measured pressure between two points. According to the measured pressure, along the height direction of the furnace, the calculated particle concentrations were $1.51,1.92$, and $2.81 \mathrm{~kg} / \mathrm{m}^{3}$ and the corresponding feed rates were $65.0,77.0$, and $89.6 \mathrm{~kg} / \mathrm{h}$, respectively. The gas-solid flows were dilute density pneumatic conveying. Particle dispersion was good. By-products in furnace were evenly heated and completely decomposed. Therefore, the minimum feed rate of $89.6 \mathrm{~kg} / \mathrm{h}$ is feasible for an industry with the same size of the industrial demonstration equipment in this article.

\section{Effect of furnace temperature (TE103) on $\mathrm{SO}_{2}$ mole fraction in calciner gas}

It is found that the effects of the furnace temperature on $\mathrm{SO}_{2}$ mole fractions were different under the conditions of different measuring points and atmosphere in calciner. This article studied the effects of the furnace temperature of the measuring point TE103 on the $\mathrm{SO}_{2}$ mole fractions under the conditions of the feed port located in the position P1, the case 1 in Table 1 (oxidizing atmosphere, $\alpha \geq 1$ ) and the position $\mathrm{P} 2$, the case 2 in Table 1 (reducing atmosphere, $\alpha<1$ ), respectively, as shown in Fig. 10.

Figure 10 illustrates that the $\mathrm{SO}_{2}$ mole fractions increased with increasing temperature under the conditions of oxidizing atmosphere and the feed port located at the position P1. Under the condition that the flow rate of nature gas was a constant value, the cold air needed for the higher temperature of the furnace decreased, which led to low flue gas volume and high $\mathrm{SO}_{2}$ mole fractions. However, under the conditions of the reducing atmosphere and the feed port located at the position $\mathrm{P} 2$, the $\mathrm{SO}_{2}$ mole fractions decreased with the increasing furnace temperature. With a furnace temperature of $927^{\circ} \mathrm{C}$, the $\mathrm{SO}_{2}$ mole fractions were $2.8 \%$; while with a furnace temperature of $1,036^{\circ} \mathrm{C}$, the $\mathrm{SO}_{2}$ mole fractions were $0.8 \%$. The reasons are as follows. Under the condition of the flow rate of nature gas being a constant value and reducing atmosphere, the air needed for the higher temperature of the furnace increased, which led to high flue gas and low $\mathrm{SO}_{2}$ mole fractions.

\section{Effect of crystal water content in by-products on the $\mathrm{SO}_{2}$ mole fractions in calciner gas}

During the experiment, it is found that moisture could not be released in a timely manner, which caused by-products to cluster and material wrapped within the cluster not to decompose. Table 1 shows that the crystal water content in byproducts is high and the temperature of losing crystal is $350^{\circ} \mathrm{C}$ for the by-products from a commercial desulfurization system (Mcglamery et al., 1973). Thus, this article studied the effect of crystal water content for cases 1-3 in Table 1 on the $\mathrm{SO}_{2}$ mole fractions in calciner gas, as shown in Fig. 11 . The feed port is located at the position P1 in this figure.

Fig. 11 shows that the $\mathrm{SO}_{2}$ mole fractions decreased with increasing crystal water content in by-products. This is because while the crystal water rises, a certain amount of heat will be required to heat and vaporize the water, resulting in an increase of natural gas and a decrease of the $\mathrm{SO}_{2}$ mole fractions in calciner gas. In addition, the water vapor in the calciner gases is not condensed, causing some heat to be lost to the environment.

Thus, a special dewatering device before calciner should be installed, so as to improve $\mathrm{SO}_{2}$ mole fractions in calciner gas.

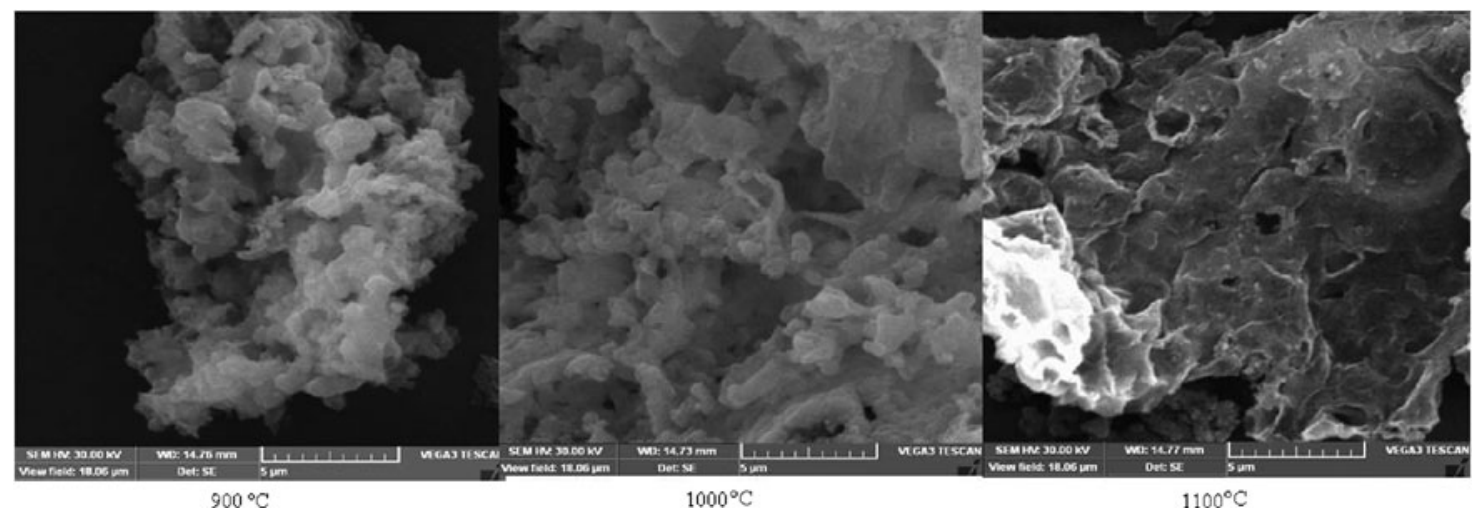

FIG. 13. SEM micrographs of $\mathrm{MgO}$. 


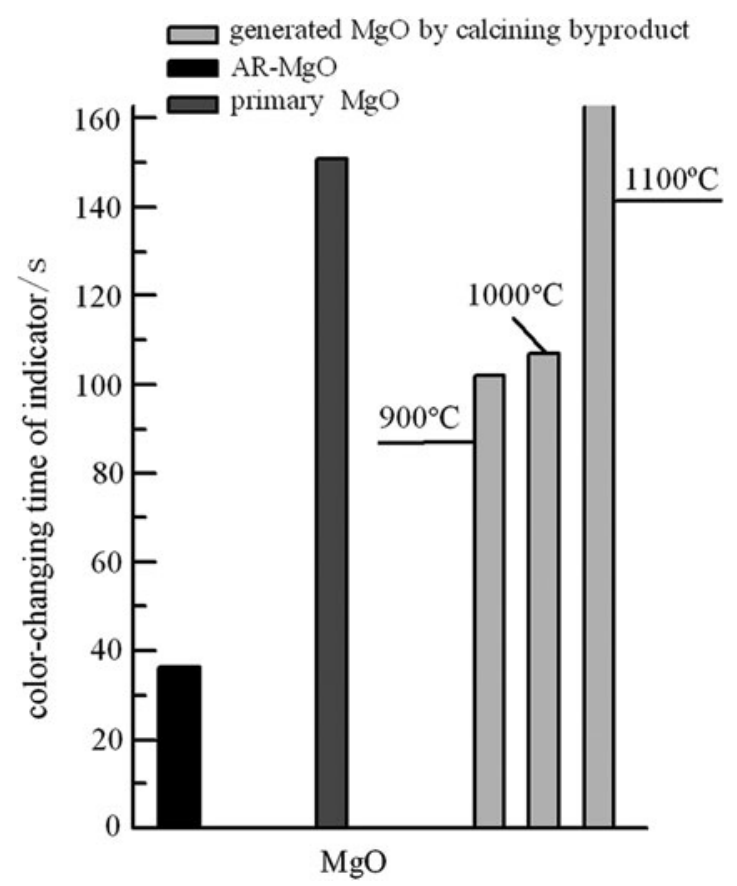

FIG. 14. Discoloration time of the indicators in citric acid test.

Earlier figures and discussions show that after the feed port was raised and crystal water content in by-products was decreased, the $\mathrm{SO}_{2}$ content in calciner gas can be increased by more than 10 times.

\section{Particle-sized distributions}

Particle-sized distributions of sample are shown in Fig. 12. It is found that the effect of the calcination temperature on the particle size distribution for $\mathrm{MgO}$ was insignificant. Among the samples, the particle sizes from the bottom slag with a $3.2 \%$ reduced quantity were larger than the particles from other locations. The concentrated particle-sized distributions from the calciner outlet and the gas-solid separator outlet ranged from 0 to $58 \mu \mathrm{m}$, whose sieving rate through a 250 mesh $(58 \mu \mathrm{m})$ sieve was $92 \%$. Thus, they can be used as a desulfurizer according to the technical specifications of the desulfurization (Ministry of Environmental Protection, 2005).

\section{SEM method}

SEM images of the generated $\mathrm{MgO}$ by calcnining byproducts are shown in Fig. 13. Figure 13 shows that the generated $\mathrm{MgO}$ at the calcination temperatures of $900^{\circ} \mathrm{C}$ and $1,000^{\circ} \mathrm{C}$, with loose and pores structure, exhibited high activity, but with dense structure and slight sintering, exhibited low activity at the calcination temperature of $1,100^{\circ} \mathrm{C}$.

\section{Citric acid test}

The discoloration time of the indicators for the reactions between the citric acid and the generated $\mathrm{MgO}$ by calcining by-products, analytical reagent $\mathrm{MgO}$, and primary $\mathrm{MgO}$ used as desulfurizer was determined and summarized in Fig. 14.
This figure shows that the discoloration time of the indicators increased with increasing calcinations temperature. The discoloration time of the indicators for the generated $\mathrm{MgO}$ at the calcination temperature of $900^{\circ} \mathrm{C}$ and $1,000^{\circ} \mathrm{C}$ was longer than that for analytical reagent $\mathrm{MgO}$, and shorter than that for the primary $\mathrm{MgO}$ used as the desulfurizer, because the gas released during calcining led to increasing particle porosity and specific surface area, which increased the activity of $\mathrm{MgO}$. If calcination temperature was $1,100^{\circ} \mathrm{C}$, the discoloration time of the indicators for the generated $\mathrm{MgO}$ was longer than that for the primary $\mathrm{MgO}$ used as desulfurizer. As a result, the activity for the generated $\mathrm{MgO}$ decreased (National development and reform commission of the People's Republic of China, 2006; Kang, 2011).

\section{Summaries}

Influencing factors of $\mathrm{SO}_{2}$ mole fractions in calciner gas, including the position of the feed port, excess air coefficient, feed rate, furnace temperature, and crystal water content in by-products, were experimentally investigated in this article. The activities of the generated $\mathrm{MgO}$ by calcining by-products at the furnace temperature of $900^{\circ} \mathrm{C}, 1,000^{\circ} \mathrm{C}$, and $1,100^{\circ} \mathrm{C}$ were also investigated in this article. The experiment was carried out in an industrial demonstration unit. The main findings of this study are as follows.

(1) After the position of the feed port of the by-products was raised from the position P1 to the position P2 and the crystal water in by-products was decreased, the feed rate increased, the amount of the air decreased, and reactions in the calciner were complete. As a result, $\mathrm{SO}_{2}$ mole fractions in calciner gas increased by more than 10 times.

(2) The $\mathrm{SO}_{2}$ mole fractions in calciner gas were mainly dependent on the excess air coefficient, feed rate of the by-products, and crystal water content in byproducts. The excess air coefficient had a strong effect on the $\mathrm{SO}_{2}$ mole fractions. The reduction in atmosphere had contributed to an increase in $\mathrm{SO}_{2}$ mole fractions, but the mole ratio of natural gas to air should be less than 1/7.2 to prevent $\mathrm{SO}_{2}$ from being reduced to element sulfur. High feed rate led to high $\mathrm{SO}_{2}$ mole fractions. By-products dewatered before calcined could improve $\mathrm{SO}_{2}$ mole fractions.

(3) The effects of the furnace temperature on $\mathrm{SO}_{2}$ mole fractions were different under the conditions of different measuring points and atmosphere in calciner. The reducing atmosphere, the feed port located at the position $\mathrm{P} 2$, and the furnace temperature controlled to $927^{\circ} \mathrm{C}$ was advantageous to increasing $\mathrm{SO}_{2}$ content.

(4) The changes of particle-sized distributions of $\mathrm{MgO}$ with different calcination temperatures may be ignored. The activity of the generated $\mathrm{MgO}$ by calcining by-products was greatly affected by calcination temperature. The generated $\mathrm{MgO}$ at the furnace temperature of $900^{\circ} \mathrm{C}$ and $1,000^{\circ} \mathrm{C}$ exhibited high activity, but exhibited low activity with slight sintering at the calcination temperature of $1,100^{\circ} \mathrm{C}$. 
(5) To recycle $\mathrm{SO}_{2}$ as well as $\mathrm{MgO}$ from by-products, the temperature range of $900-920^{\circ} \mathrm{C}$ for $\mathrm{TE} 103$ is proposed.

\section{Acknowledgments}

The authors gratefully acknowledge the support provided by the Innovation Fund for Technology-Based Firms, Ministry of Science and Technology of China (11c26215115764), Sunic Energy and Environment Technologies (Chongqing) Co., Ltd., and the Technology Planning Project of Jiangxi Province of China (Grant No. 20122BBG70087).

\section{Author Disclosure Statement}

No competing financial interests exist.

\section{Nomenclature}

IEA: international energy agency

WFGD: wet flue gas desulfurization

FGD: flue gas desulfurization

SP: sampling point

TE: temperature-measuring point

PT: pressure measuring point

P1: the original position of feed port

P2: the position after heightening feed port

$\mathrm{M}_{\mathrm{b}}$ : feed rate of by-products, $\mathrm{kg} / \mathrm{h}$

$\mathrm{V}_{\mathrm{a}}$ : air flow rate, $\mathrm{Nm}^{3} / \mathrm{h}$

$\mathrm{V}_{\text {ng }}$ : nature gas flow rate, $\mathrm{Nm}^{3} / \mathrm{h}$

T: temperature, ${ }^{\circ} \mathrm{C}$

t: time, $\min$

$\mathrm{h}$ : height along the furnace, $\mathrm{mm}$

SEM: scanningelectron microscope

$\alpha$ : excess air coefficient

$V$ : actual air volume for fuel combustion

$V_{0}$ : Theoretical air volume for fuel complete combustion

$\rho_{\mathrm{p}}:$ particle concentration, $\mathrm{kg} / \mathrm{m}^{3}$

$\Delta \mathrm{P}$ : pressure difference along the axial direction of furnace, $\mathrm{Pa}$

$g$ : acceleration of gravity, $9.8 \mathrm{~m} / \mathrm{s}^{2}$

$\Delta \mathrm{h}$ : the height difference between two points, $\mathrm{m}$

AR: analytical reagent

\section{References}

Bitsko, R., and Helt, R.W. (1991). Progress and problems with magnesiumoxide regenerable scrubbers. In Proceedings of the 53rd Annual American Power Conference, Chicago, USA, 29 Apr-1 May.

Chai, M., Cui, K., Xu, F.K., and Ma, Y.L. (2006). Technical and economic feasibility analysis of recovery flue gas desulphurization with magnesium oxide. Tech. Equip. Environ. Pollut. Control. 7, 38. (In Chinese.)

Chen, H., Ge, H.H., Dou, B.L., Pan, W.G., and Zhou, G.D. (2009). Thermogravimetric kinetics of $\mathrm{MgSO}_{3} \cdot 6 \mathrm{H}_{2} \mathrm{O}$ byproduct from magnesia wet FGD. Energy Fuels. 23, 2552.

Gangwal, S.K., and Porter, J.W. (1995). Slipstream Testing of Hot-Gas Desulfurization with Sulfur Recovery. Morgantown, VA: U. S. Department of Energy.
Guo, Q. (2011). A study on magnesia FGD regeneration technology. Nonferrous Met. Eng. Res. 32, 37. (In Chinese.)

Guo, R.T., Pan, W.G., Zhang, X.B., Xu, H.J., and Ren, J.X. (2011). Dissolution rate of magnesium hydrate for wet flue gas desulfurization. Fuel. 90, 7.

International Energy Agency. (2012). Medium-Term Coal Market Report 2012-Market Trends and Projections to 2017. Paris: International Energy Agency.

Kang, W.Z. (2011). Research on Resources Utilization of byProduct from FGD Employing Magnesium Process. Ph.D. Dissertation, East China University of Science and Technology, Shanghai, China. (In Chinese.)

Koyama, H. (1998). Apparatus for Desulfurization of Flue Gases with Recycling Magnesium Oxide and Recovering Sulfuric Acid. Japan Patent 10109013.

Little, D. (1997). Advanced by-Product Recovery: Direct Catalytic Reduction of $\mathrm{SO}_{2}$ to Elemental Sulfur, Seventh Quarterly Technical Progress Report. Department of Energy Pittsburgh Energy Technology Center, Pittsburgh.

McGlamery, G.G., Torstrick, R.L., Simpson, J.P., and Phillips, J.F.Jr. (1973). Sulfur Oxide Removal from Power Plant Stack Gas-Magnesia Scrubbing-Regeneration, Production of Concentrated Sulfuric Acid. Alexandria, VA: National Technical Information Service.

Ministry of Environmental Protection. (2005). Flue Gas Limestone/Lime Gypsum Desulfurization Project Technical Specification of Thermal Power Plant. HJ/T179-2005. (In Chinese.)

Ministry of Environmental Protection and AQSIQ. (2011). Emission Standard of Air Pollutants for Thermal Power Plants, National Standard of the People's Republic of China. GB.13223-2011. (In Chinese.)

National development and reform commission of the People's Republic of China. (2006). Test Methods for Chemical Activity of Caustic Burned Magnesia. YB/T4019-2006. (In Chinese.)

Pradyot, P. (2003). Handbook of Inorganic Chemicals. New York: McGraw-Hill.

Recelj, T., and Golob, J. (2001). Absorption of $\mathrm{SO}_{2}$ in the $\mathrm{MgO}$ $\mathrm{SO}_{2}-\mathrm{H}_{2} \mathrm{O}$ and in the $\mathrm{Ca}^{2+}-\mathrm{SO}_{2}-\mathrm{H}_{2} \mathrm{O}$ system. Chem. Biochem. Eng. Q. 15, 153.

Rosemount Analytical, Inc. (2013). Magnesium Oxide Wet Scrubbing System for Flue Gas Desulfurization. Irvine, CA: Emerson process management.

Sajan, K., Chandrakala, K., Ravish, V., and Anurag, M. (2007). Gas absorption in slurries of fine particles: $\mathrm{SO}_{2}-\mathrm{Mg}(\mathrm{OH})_{2}-$ $\mathrm{MgSO}_{3}$ system, Ind. Eng. Chem. Res. 46, 1904.

Sargent and Lundy. (2003). Wet Flue Gas Desulfurization Technology Evaluation. Chicago: National Lime Association.

Scheidema, M.N., and Taskinen, P. (2011). Decomposition thermodynamics of magnesiumsulfate. Ind. Eng. Chem. Res. $50,9550$.

Shen, Z.G., Chen, X., Tong, M., Guo, S.P., Ni, M.J., and Lu, J. (2013). Studies on magnesium-based wet flue gas desulfurization process with oxidation inhibition of the byproduct. Fuel. 105, 578.

Shen, Z.G., Guo, S.P., Kang, W.Z., Zeng, K., Yin, M., Tian, J.Y., and Lu, J. (2012). Kinetics and mechanism of sulfite oxidation in the magnesium-based wet flue gas desulfurization process. Ind. Eng. Chem. Res. 51, 4192.

State environmental protection administration. (1996). Determination of Particulates and Sampling Methods of 
Gaseous Pollutants Emitted from Exhaust Gas of Stationary Source. GB/T/16157-1996. (In Chinese.)

Sun, C., Chen, X.A., Chang, X.A., Xiao, W.Q., and Wang, S.H. (2013). Study on preparation of magnesia from anhydrous magnesium sulfate reduced by carbon monoxide. Inorg. Chem. Ind. 45, 14. (In Chinese.)

United States Environmental Protection Agency. (1981). Sulfur Oxides Control Technology Series: Flue Gas Desulfurization, Magnesium Oxide Process. Research Triangle Park, NC: Indusrial Environmental Research Laboratory.

Wang, L.D., Ma, Y.L., Zhang, W.D., Li, Q.W., Zhao, Y., and Zhang, Z.C. (2013). Macrokinetics of magnesium sulfite oxidation inhibited by ascorbic acid. J. Hazard. Mater. 258$259,61$.

Wang, Z.Y., Zhu, T., Wang, J., Yu, F., Zhang, Q.L., and He, W.Z. (2010). A Kind of Process Drying and Calcining Desulfurization by-Product $\mathrm{MgSO}_{3}$. Chinese Patent 201010580884.4.

Xiong, T.Y. (2005). $\mathrm{SO}_{2}$ in Exhaust Gas Is Removed and Made as Product by Recycling $\mathrm{MgO}$. Chinese Patent 200510080481.2.
Xiong, T.Y. (2013). A system and Method Recycling MgO and $\mathrm{SO}_{2}$ by the Thermal Decomposition of $\mathrm{MgO}$ Desulfurization by-Product. Chinese Patent 201310048080.3.

Xu, H.J., Zhang, C., and Ge, H.H. (2010). Simulation and optimation of processes of magnesia FGD. J. Shanghai Univ. Electric Power 2, 145. (In Chinese.)

Yi, D.M., Wei, L., and Luo, J. (2009). Sulfuric Acid Is Obtained by Mixture Included in $\mathrm{MgSO}_{3}$. ZL200910034218.8.

Zhang, J.J., Feng, Y.L., and Li, H.R. (2010). Preparation of magnesia by solid phase direct decomposition of magnesium sulfate. Inorg. Chem. Ind. 42, 11. (In Chinese.)

Zhang, Y.B., Chen, Y.M., and Ma, Y.L. (2011). Effects of several crystallization condition on the recovery of desulfurization by-products. Ind. Saf. Environ. Prot. 37, 32 (in Chinese).

Zhou, X.L., Cheng, L.M., Zhang, J.C., Wang, Q.H., Luo, Z.Y., and Cen, K.F. (2012). Experimental study on solids suspension density and solids circulating rate in a CFB with six circulating loops. Proceedings of the CSEE. 32, 8 (In Chinese.) 